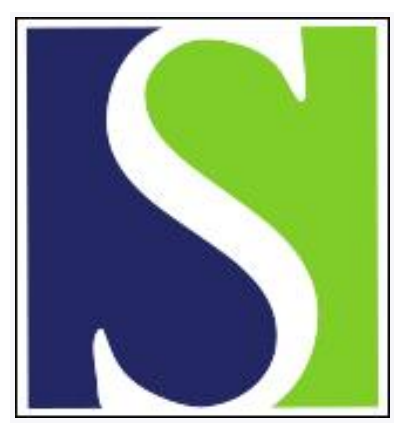

Scand J Work Environ Health 1986;12(1):46-50

https://doi.org/10.5271/sjweh.2175

Issue date: Feb 1986

Respiratory disease in cotton textile workers in the People's Republic of China. II. Pulmonary function results.

by Christiani DC, Eisen EA, Wegman DH, Ye TT, Gong ZC, Lu PL, Dai HL

This article in PubMed: www.ncbi.nlm.nih.gov/pubmed/3961441

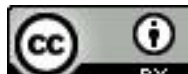




\title{
Respiratory disease in cotton textile workers in the People's Republic of China
}

\section{Pulmonary function results}

\author{
by David C Christiani, MD, MPH, ${ }^{1}$ Ellen A Eisen, ScD, ${ }^{1}$ David H Wegman, MD, MS, ${ }^{2}$ Ting-ting Ye, ${ }^{3}$ \\ Zhi-chu Gong, ${ }^{3}$ Pei-lian Lu, ${ }^{3} \mathrm{He}$-lian Dai ${ }^{3}$
}

\begin{abstract}
CHRISTIANI DC, EISEN EA, WEGMAN DH, YE T-T, GONG Z-C, LU P-L, DAI H-L. Respiratory disease in cotton textile workers in the People's Republic of China: II Pulmonary function results. Scand $J$ Work Environ Health 12 (1986) 46-50. Pulmonary function tests were performed pre and post workshift on 887 textile workers with at least two years of employment in two cotton mills and one silk mill in Shanghai, the People's Republic of China. Environmental sampling was performed with vertical elutriators, and pulmonary function was performed with standardized techniques. Cotton textile workers were found to have greater across-shift decrements in forced expiratory volume in $1 \mathrm{~s}\left(\mathrm{FEV}_{1.0}\right)$ than silk workers. Increasing duration of exposure resulted in increasing acute decrements in $\mathrm{FEV}_{1.0}$, although significant acute decrements were found in work rrs with less than five years of exposure. The acute changes in $\mathrm{FEV}_{1.0}$ were noted in both symptomatic and asymptomatic cotton workers, though the difference between the across-shift change in $\mathrm{FEV}_{1.0}\left(\Delta \mathrm{FEV}_{1.0} \%\right)$ of the byssinotics and nonbyssinotics increased as work duration increased. There was no difference in preshift FEV $_{1.0}$ between the cotton and silk workers, but several selection factors likely influenced the observations.
\end{abstract}

Key terms: byssinosis, cotton dust, pulmonary function in textile workers.

Cotton production and consumption has expanded rapidly in developing nations during the past decade (12). The People's Republic of China is a major cotton producer, currently the world's largest consumer of cotton (11), and the number of workers in cotton processing continues to grow annually. But epidemiologic studies of cotton textile workers in China using the survey techniques of studies in the United States and the United Kingdom have not been performed.

Although the characteristic feature of byssinosis in workers who are exposed to cotton dust is chest tightness occurring on the first day back to work after an absence, changes in objective measurements of pulmonary function over the workshift have also been demonstrated. Not all byssinotic workers have changes in lung function, but as a group they tend to have greater reductions in the forced expiratory volume in $1 \mathrm{~s}\left(\mathrm{FEV}_{1.0}\right)$ over the workshift than asymptomatic workers (3). Moreover, the prevalence of byssinotic symptoms and decrements in pulmonary function have been shown to increase with increasing dust exposure (15).

1 Occupational Health Program, Harvard School of Public Health, Boston, Massachusetts, United States.

2 Southern Occupational Health Center, School of Public Health, University of California at Los Angeles, Los Angeles, California, United States.

3 Occupational Health Department, Shanghai First Medical College, Shanghai, The People's Republic of China.

Reprint requests to: Dr DC Christiani, Occupational Health Program, Harvard School of Public Health, 665 Huntington Ave, Boston, MA 02115, USA.
The overall objective of this study was to examine cotton-related respiratory effects in a Chinese textile worker population. The prevalence of respiratory symptoms and the relations between symptoms and exposures have been presented in the preceding paper (7). In this report, measurements of pulmonary function on the same population are presented along with the relationships between pulmonary function, exposures, and symptoms.

\section{Materials and methods}

Definitions, the study design, and the methods used in collecting the data are found in the Methods section of the preceding paper (7).

\section{Pulmonary function tests}

Pulmonary function tests were performed before the subjects entered the work area after a rest period of $2 \mathrm{~d}$ and at the end of the same day. Workers were asked to refrain from smoking for at least $1 \mathrm{~h}$ before performing the test. Forced expiratory maneuveurs were recorded for each worker on an 8-1 Stead-Wells spirometer (WE Collins Co) under the direction of one technician. Each worker performed up to seven trials to produce three acceptable curves according to the American Thoracic Society's criteria for standardization of spirometric techniques (10). The spirometric curves were read manually with the starting point defined by back extrapolation. The lung function indices included forced expiratory volume in $1 \mathrm{~s}$ 
$\left(\mathrm{FEV}_{1.0}\right)$ and forced vital capacity (FVC). Acceptable $\mathrm{FEV}_{1.0}$ tracings were allowed to vary by no more than $10 \%$ or $100 \mathrm{ml}$, whichever was greater, and the best $\mathrm{FEV}_{1.0}$ and FVC was used regardless of whether they were on the same tracing. All values were corrected to conditions of body temperature and pressure saturated with water vapor (BTPS). The highest values for $\mathrm{FEV}_{1.0}$ and FVC were used for subsequent analyses, provided that these values came from technically acceptable blows. The best $\mathrm{FEV}_{1.0}$ was expressed as the percentage of best FVC $\left(\mathrm{FEV}_{1.0} / \mathrm{FVC} \%\right)$ and for each worker the change in $\mathrm{FEV}_{1.0}$ occurring over the workshift was expressed as a percentage as follows:

$\Delta \mathrm{FEV}_{1.0}=\mathrm{FEV}_{1.0}$ after shift $-\mathrm{FEV}_{1.0}$ before shift. $\Delta \mathrm{FEV}_{1.0} \%=\Delta \mathrm{FEV}_{1.0} \times 100 /\left(\mathrm{FEV}_{1.0}\right.$ before shift $)$.

In the adjustments for differences in stature, each individual's own preshift $\mathrm{FEV}_{1.0}$ served as the base line.

\section{Statistical analysis}

Linear regression was used to model the effects of exposure on baseline pulmonary function (preshift $\left.\mathrm{FEV}_{1.0}\right)$ and on acute change in pulmonary function $\left(\Delta \mathrm{FEV}_{1.0} \%\right)$ over a workshift. The confounding effects of age, height, gender, and smoking were adjusted for in each model. Exposure was defined either categorically (exposed or unexposed) or as a continuous measurement of the elutriated dust level in each work area.

With the silk workers as a reference group, prediction equations for baseline (preshift) $\mathrm{FEV}_{1.0}$ were generated after adjustment for age, height, and smoking. A percent predicted $\mathrm{FEV}_{1.0}$ was obtained for each cotton textile worker by expressing the observed value as a percentage of the predicted value. For all pulmonary function models, separate regression models were estimated for the men and women:

Females: $\mathrm{FEV}_{1.0}(\mathrm{l})=-0.023$ age (years) +0.033 height $(\mathrm{cm})-1.837$

Males: $\mathrm{FEV}_{1.0}(\mathrm{l})=-0.028$ age (years) +0.055 height $(\mathrm{cm})-0.010$ smoking (pack-years) -4.800

The six women who smoked were excluded leaving a model based on 210 female silk workers [coefficient of determination $\left(\mathrm{R}^{2}\right)=0.501$ ]. A term for pack-years of cigarette smoking was included for the men and resulted in a model for men based on 160 silk workers $\left(R^{2}=0.604\right)$.

\section{Results}

Demographic data on the cotton- and silk-exposed populations are shown in table 1 . The populations did not differ significantly with regard to age, duration of work, or adjusted mean $\mathrm{FEV}_{1.0}$. The prevalence of smoking (only one exsmoker) among the cotton textile workers was significantly greater than that of the silk textile workers $(\mathrm{p}<0.001)$, although the average amount smoked by smokers was the same in the two groups.

The cotton textile workers had more chronic cough and chronic bronchitis than the silk workers. The prevalence of byssinosis was $7.6 \%$ among the cotton workers and zero among the silk workers. Ninety-one percent of the cotton workers and $83 \%$ of the silk workers successfully performed pre- and postshift spirometry. A total of 39 cotton textile workers and 75 silk workers had unacceptable curves either by the reproducibility criteria or by an inability to perform any forced expiratory maneuver. There were no differences in preshift adjusted FEV $_{1.0}$ or FVC. However, the cotton textile workers had a larger mean across-shift decrement than the silk textile workers $(-2.0 \%$ versus $+0.3 \%$, respectively). In order to look further at these findings, we divided the cotton textile workers into those with and without byssinosis (table 2).

The byssinotic cotton textile workers were slightly older and had slightly longer work tenures than the nonbyssinotic workers. Most workers reporting byssinosis symptoms were women, and hence the smoking prevalence among byssinotics was lower than among nonbyssinotics. Five of the 34 byssinotics $(15 \%)$ had spirograms which did not satisfy the reproducibility criteria (see the preceding results) as did 34 nonbyssinotics $(9.1 \%)$. Byssinotic workers had a decreased baseline $\mathrm{FEV}_{1.0}$ and $\mathrm{FEV}_{1.0} / \mathrm{FVC} \%$ and greater across-shift decrements in $\mathrm{FEV}_{1.0}$ than did nonbyssinotic cotton workers, though the differences were significant only for $\mathrm{FEV}_{1.0} / \mathrm{FVC} \%(\mathrm{p}<0.0001)$.

Regression analysis of the acute change in $\mathrm{FEV}_{1.0}$ in the total population across the workshift is shown

Table 1. Raw data on exposed and control populations. (SEM = standard error of the mean, $\mathrm{FEV}_{10}=$ forced expiratory volume in $1 \mathrm{~s}, \mathrm{FVC}=$ forced vital capacity)

\begin{tabular}{|c|c|c|}
\hline & Cotton workers & Silk workers \\
\hline Number & 448 & 439 \\
\hline $\begin{array}{l}\text { Mean age } \\
\text { (years) } \pm \text { SEM }\end{array}$ & & $35.7 \pm 0.51$ \\
\hline Mean work tenure & & \\
\hline $\begin{array}{l}\text { (years) } \pm \text { SEM } \\
\text { Percent male }\end{array}$ & $\begin{array}{l}16.3 \pm 0.49 \\
47.8\end{array}$ & $\begin{array}{l}16.7 \pm 0.57 \\
42.1\end{array}$ \\
\hline Percent smokers & 33.9 & 23.2 \\
\hline $\begin{array}{l}\text { Mean average amount } \\
\text { smoked (pack-years) for }\end{array}$ & & \\
\hline $\begin{array}{l}\text { smokers } \pm \text { SEM } \\
\text { Symptom prevalence (\%) }\end{array}$ & $9.70 \pm 0.81$ & $9.07 \pm 0.99$ \\
\hline Chronic cough & 19.2 & 6.8 \\
\hline Chronic bronchitis & 21.2 & 7.1 \\
\hline $\begin{array}{l}\text { Byssinosis } \\
\text { Pulmonary function }\end{array}$ & 7.6 & 0 \\
\hline $\begin{array}{l}\text { Pulmonary function } \\
\text { Mean FEV }_{1.0}(\mathrm{l}) \pm \mathrm{SEM}\end{array}$ & $2.90 \pm 0.03$ & $2.90 \pm 0.04$ \\
\hline Mean percent predic- & & \\
\hline $\begin{array}{l}\text { ted } \mathrm{FEV}_{1,0} \pm \text { SEM } \\
\text { Mean FVC (I) } \pm \text { SEM }\end{array}$ & $\begin{array}{r}99.60 \pm 0.67 \\
3.50 \pm 0.04\end{array}$ & $\begin{array}{l}100.00 \\
3.50 \pm 0.04\end{array}$ \\
\hline $\begin{array}{l}\text { ted FVC } \pm \text { SEM } \\
\text { Mean FEV } 1.0 / F V C \%\end{array}$ & $\begin{aligned} 99.96 & \pm 0.61 \\
82.7 & \pm 0.004\end{aligned}$ & $\begin{array}{c}100.00 \\
84.2 \pm 0.004\end{array}$ \\
\hline SEM & $-0.06 \pm 0.008$ & $-0.00 \pm 0.008$ \\
\hline SEM & $-2.0 \pm 0.34$ & $+0.30 \pm 0.28$ \\
\hline
\end{tabular}


Table 2. Demographic characteristics and pulmonary function in cotton textile workers with and without byssinosis. (SEM $=$ standard error of the mean, FEV $_{1.0}=$ forced expiratory volume in $1 \mathrm{~s}, \mathrm{FVC}=$ forced vital capacity).

\begin{tabular}{|c|c|c|}
\hline & \multicolumn{2}{|c|}{ Cotton workers } \\
\hline & $\begin{array}{c}\text { With } \\
\text { byssinosis } \\
(\mathrm{N}=34)\end{array}$ & $\begin{array}{l}\text { Without } \\
\text { byssinosis } \\
(\mathrm{N}=411)^{\mathrm{a}}\end{array}$ \\
\hline \multirow{4}{*}{ 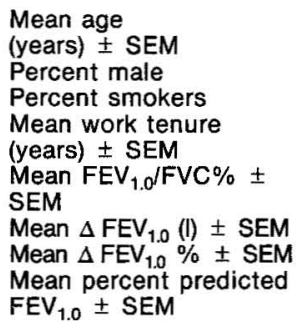 } & $\begin{array}{l}40.5 \pm 1.89 \\
26.5 \\
29.4\end{array}$ & $\begin{array}{c}37.1 \pm 0.52 \\
73.5 \\
34.2\end{array}$ \\
\hline & $18.8 \pm 1.80$ & $16.0 \pm 0.51$ \\
\hline & $\begin{array}{r}80.2 \pm 0.02 \\
-0.10 \pm 0.03 \\
-3.75 \pm 1.20\end{array}$ & $\begin{array}{r}82.9 \pm 0.004 \\
-0.05 \pm 0.008 \\
-1.87 \pm 0.28\end{array}$ \\
\hline & $96.53 \pm 2.91$ & $99.82 \pm 0.68$ \\
\hline
\end{tabular}

a Five of 34 byssinotics did not have acceptable pulmonary function tests and were excluded. Thirty-four of 411 nonbyssinotics did not have acceptable pulmonary function tests and were excluded.

Table 3. Regression analysis of change in percent of forced expiratory volume in $1 \mathrm{~s}(\Delta \mathrm{FEV}, \%)$ in 767 textile workers. Outcome: $\Delta \mathrm{FEV}_{1.0} \%$ over workshift. $^{\mathrm{a}}$

\begin{tabular}{lll}
\hline Variable & Beta & $\mathrm{p}>\mathrm{t}$ \\
\hline Intercept & +0.276 & 0.731 \\
Age & +0.004 & 0.855 \\
Smoking & +0.526 & 0.414 \\
Genderc $^{\mathrm{b}}$ & -0.574 & 0.338 \\
Exposure $^{\mathrm{d}}$ & -2.32 & 0.0001 \\
\hline
\end{tabular}

a $\mathrm{R}^{2}=0.034$.

b Smoking $=0$ if no, $=1$ if yes.

c Gender: $0=$ female, $1=$ male.

d Exposure: 0 = silk worker; 1 = cotton worker.

Table 4. Regression model for relationship between byssinosis and acute change in forced expiratory volume in $1 \mathrm{~s}(\Delta \mathrm{FEV}, \mathrm{H}$ in cotton textile workers over a workshift. Outcome: $\Delta \mathrm{FEV}_{1.0} \%$ over a workshift. ${ }^{a}$

\begin{tabular}{lcc}
\hline Covariate & Beta & $\mathrm{p}>\mathrm{t}$ \\
\hline Intercept & -0.3447 & 0.7397 \\
Age & -0.0427 & 0.1084 \\
Smoking $^{\mathrm{b}}$ & -0.2127 & 0.7148 \\
Byssinosis $^{\mathrm{c}}$ & -1.691 & 0.1159 \\
\hline
\end{tabular}

a $\mathrm{N}=403, \mathrm{R}^{2}=0.014$.

b Smoking $=0$ if no, 1 if yes.

- Byssinosis $=0$ if no, 1 if yes.

Table 5. Acute change in forced expiratory volume in $1 \mathrm{~s}$ $\left(\Delta F E V_{1.0}\right)$ in cotton and silk textile workers, with various work tenures, over a workshift. (SEM = standard error of the mean).

\begin{tabular}{|c|c|c|c|c|c|c|}
\hline \multirow{2}{*}{$\begin{array}{l}\text { Years } \\
\text { worked }\end{array}$} & \multicolumn{3}{|c|}{ Cotton } & \multicolumn{3}{|c|}{ Silk } \\
\hline & $N$ & $\underset{(\%)}{\Delta \text { FEV }_{1.0}}$ & SEM & $\mathrm{N}$ & $\underset{(\%)}{\Delta \mathrm{FEV}_{1.0}}$ & SEM \\
\hline $\begin{array}{l}2-5 \\
6-10 \\
11-20 \\
>20\end{array}$ & $\begin{array}{r}63 \\
86 \\
97 \\
155\end{array}$ & $\begin{array}{l}-1.79 \\
-1.01 \\
-1.91 \\
-2.68\end{array}$ & $\begin{array}{l}0.72 \\
0.60 \\
0.61 \\
0.42\end{array}$ & $\begin{array}{r}74 \\
64 \\
88 \\
130\end{array}$ & $\begin{array}{l}+0.62 \\
-0.23 \\
-0.72 \\
+0.99\end{array}$ & $\begin{array}{l}0.67^{\star} \\
0.64 \\
0.51 \\
0.72^{\star *}\end{array}$ \\
\hline
\end{tabular}

* $p<0.01,{ }^{* *} p<0.001$. in table 3. After the effects of age and smoking were allowed for, $\Delta \mathrm{FEV}_{1.0} \%$ was shown to be strongly associated with exposure to cotton dust ( $\mathrm{p}=0.0001$ ). Large acute decrements $\left(\Delta \mathrm{FEV}_{1.0} \%\right)$ were observed in both the male and female cotton workers. When cotton workers alone were considered, however, the relationship between elutriated dust level and the acute change in $\mathrm{FEV}_{1.0}$ was not significant (analysis not shown).

When only cotton textile workers are considered and age and smoking are allowed for, byssinosis was associated with a. greater across-shift decline in $\Delta \mathrm{FEV}_{1.0} \%(\mathrm{p}=0.12)$ (table 4$)$. No interaction was found between smoking and cotton dust exposure in the production of the across-shift $\Delta \mathrm{FEV}_{1.0} \%$.

An analysis of the relation between an acute change in $\mathrm{FEV}_{1.0}$ and the duration of work showed that even among workers with less than five years of work in the mills, the cotton workers had a larger decrement in $\Delta \mathrm{FEV}_{1.0} \%$ than the silk workers $(-1.8 \%$ versus $+0.62 \%$, respectively, $\mathrm{p}<0.01$ ) (table 5). Furthermore, among the cotton workers, increasing work duration in the mill was associated with increasingly large drops in $\mathrm{FEV}_{1.0}$ observed over the workshift, being $-2.7 \%$ among workers with a work tenure greater than 20 years compared with a gain of $1 \%$ among silk workers with the same duration of employment in the mills. We then looked at the relation between acute change in $\mathrm{FEV}_{1.0}$ and employment duration among the cotton workers only, according to the presence of byssinosis symptoms. Byssinotics tended to have larger across-shift decrements than nonbyssinotic cotton textile workers in each category of work duration (table 6). The difference between the

Table 6. Acute change in forced expiratory volume in $1 \mathrm{~s}$ $\left(\Delta \mathrm{FEV}_{10}\right)$ in cotton textile workers with and without byssinosis, with various work tenures, and over a workshift. (SEM = standard error of the mean).

\begin{tabular}{|c|c|c|c|c|c|c|c|c|}
\hline \multirow{2}{*}{$\begin{array}{l}\text { Years } \\
\text { worked }\end{array}$} & \multicolumn{4}{|c|}{ With byssinosis } & \multicolumn{4}{|c|}{ Without byssinosis } \\
\hline & $N$ & $\%$ & $\begin{array}{c}\Delta \mathrm{FEV}_{1.0} \\
(\%)\end{array}$ & SEM & $\mathrm{N}$ & $\%$ & $\begin{array}{c}\Delta \mathrm{FEV}_{1.0} \\
(\%)\end{array}$ & SEM \\
\hline $\begin{array}{l}2-10 \\
11-20 \\
>20\end{array}$ & $\begin{array}{r}7 \\
7 \\
15\end{array}$ & $\begin{array}{r}5 \\
7 \\
17\end{array}$ & $\begin{array}{l}-1.65 \\
-5.20 \\
-4.05\end{array}$ & $\begin{array}{l}1.99 \\
2.16 \\
1.90\end{array}$ & $\begin{array}{r}138 \\
93 \\
140\end{array}$ & $\begin{array}{l}95 \\
93 \\
83\end{array}$ & $\begin{array}{l}-1.36 \\
-1.68 \\
-2.54\end{array}$ & $\begin{array}{l}0.48 \\
0.61 \\
0.42\end{array}$ \\
\hline
\end{tabular}

Table 7. Regression model for preshift forced expiratory volume in $1 \mathrm{~s}\left(\mathrm{FEV}_{10}\right)$ in 777 textile workers. Outcome: preshift $\mathrm{FEV}_{1.0}{ }^{\mathrm{a}}$

\begin{tabular}{lrc}
\hline Variable & Beta & $\mathrm{p}>\mathrm{t}$ \\
\hline Intercept & 3.752 & 0.0001 \\
Age & -0.035 & 0.0001 \\
Height & 0.045 & 0.0001 \\
Smoking & -0.011 & 0.0001 \\
Gender $^{\mathrm{c}}$ & 0.986 & 0.0001 \\
Exposure $^{\text {d }}$ & 0.041 & 0.210 \\
\hline a $^{2}=0.590$. & \\
b Smoking = 0 if no, 1 if yes. & \\
c Gender = 0 if female, 1 if male. & \\
d Exposure = 0 if silk, 1 if cotton. &
\end{tabular}


$\Delta \mathrm{FEV}_{\mathrm{I} .0} \%$ of the byssinotics and nonbyssinotics increased as work duration increased.

The effect of exposure on chronic ventilatory function (preshift $\mathrm{FEV}_{1.0}$ ) was also examined by regression analysis. As with $\Delta \mathrm{FEV}_{1.0} \%$, the potential confounders of age, height, and smoking were controlled for in the model. Work in a cotton mill was not associated with a lower preshift $\mathrm{FEV}_{1.0}(\mathrm{p}=0.21)$ (table 7).

\section{Discussion}

Acute changes in forced expiratory volume in one second

This study demonstrates that cotton textile workers have greater acute decrements in $\mathrm{FEV}_{1.0}$ across a workshift than noncotton textile workers. These greater decrements were present in cotton textile workers who were exposed to elutriated dust levels of 0.45 to $1.5 \mathrm{mg} / \mathrm{m}^{3}$ from processing medium to highquality cotton. Acute decrements in $\mathrm{FEV}_{1.0}$ were significantly greater among the exposed cotton workers than among the silk workers. In an internal analysis of cotton workers no relation was found between vertical elutriated dust levels and acute change in FEV $_{1.0}$, but the range of exposures was narrow and could have obscured a significant exposure effect. The acute decreases in function were observed in both symptomatic and asymptomatic workers, and in both men and women upon exposure to dust after a $2 \mathrm{~d}$ rest. These results support findings of earlier investigators $(3,13,14)$. The fact that virtually all the cotton used in these mills was hand-picked provides some evidence against the hypothesis that hand-picked cotton contains lower trash content and is therefore less "potent" than machine-picked cotton. It is quite possible that handpicking results in grossly cleaner cotton (less soil and stem contamination) but not in less bract content. Since at least some of the active agents are located in bract (6), hand-picking is not sufficient to remove the responsible agents.

There were three trends noted in regard to work duration and health effects. First, with increasing years worked in the cotton mills, there was an increasing prevalence of byssinosis $-17 \%$ among workers with at least 20 years in the mills (7). Second, there was an increasing across-shift decrement in $\mathrm{FEV}_{1.0}$ with increasing years of exposure. This effect was greater in byssinotics, but occurred in nonbyssinotics as well, after 20 years of work. Third, cotton workers with less than five years in the mills had larger acute decreases in $\mathrm{FEV}_{1.0}$ than silk workers with the same work tenure.

Given the rather marked evidence for acute change in ventilatory capacity, an explanation for the relatively low prevalence of byssinosis symptoms needs to be offered. In previous studies the prevalence of all grades of byssinosis has been found to be a function of the type of exposure, the length of exposure, the quality of raw cotton, and the level of elutriated dust being processed. Though initially described in Lancashire and Northern Ireland, byssinosis is now known to occur world-wide, despite the fact that reports from Eastern Europe and developing nations are few. The prevalence of byssinosis reported in this study, 7.6\% (mostly mild, or grade 1/2), is one of the lowest reported, but an informal medical removal policy may be accountable. Evidence has been presented in a previous study (7) that such a "healthy worker effect" operates in these mills. Plant physicians stated that workers who develop respiratory diseases such as tuberculosis or "asthma" are systematically removed from areas of cotton dust exposure. This medical removal policy could lead to an underestimate of the true prevalence of byssinosis.

\section{Chronic change in forced expiratory volume in one second}

The cotton exposed workers with byssinosis had a lower percent-predicted FEV $_{1.0}$ than those without byssinosis, although this difference was not significant. This cross-sectional study, however, revealed no significant reduction in preshift $\mathrm{FEV}_{1.0}$ in cottonexposed workers as compared with silk workers. It is possible that longer work tenure might lead to a significant association. It is also possible that exposure at these levels is not associated with chronic pulmonary impairment if acute reactors are selected out.

Several studies (none from developing countries to date) support the hypothesis that there is a more rapid loss of ventilatory function in cotton textile workers than in referents. Berry et al (3) demonstrated greater annual decrements in $\mathrm{FEV}_{1.0}$ (54 ml per year) and FVC in Lancashire cotton textile workers than in workers processing synthetic fibers ( $32 \mathrm{ml}$ per year). The workers in that study had a median work tenure of $15-19$ years and were followed for three years. A survivor population of active and retired cotton textile workers in South Carolina had lower FEV 1.0 and FVC levels than nontextile community referents from Connecticut $(1,4,16)$, and an older study of 18 plants in the United States concluded that chronic lung disease was more prevalent in cotton textile workers and that there was a "significant deficit in predicted normal FEV $_{1.0}$ " in carders $(4.9 \%)$ compared with noncarders $(0.6 \%)(5)$. Prospective follow-up studies in Yugoslavia revealed that chronic changes in pulmonary function develop only after prolonged exposure to cotton dust (17). More recently, a prospective study on chronic lung disease in American cotton textile workers (active and retired) also demonstrated an accelerated annual $\mathrm{FEV}_{1.0}$ decrement $(42 \mathrm{ml})$ in comparison with referents $(25 \mathrm{ml})$ and that the chronic losses continued after exposure to cotton dust had ended (2).

In our study the relationship reported between pulmonary function and exposure may have been under- 
estimated due to an additional selection factor. Five of 34 byssinotics $(15 \%)$ could not perform repeatable pulmonary function tests and were therefore not included in the analysis of the pulmonary function data. In another study of this population, the failure to satisfy the standard repeatability criteria was shown to be associated with byssinosis (9). Furthermore, the authors found that the preshift $\mathrm{FEV}_{1.0}$ of subjects excluded due to poor test performance were, on the average, lower than the pulmonary function included in the analysis.

We conclude from this study that Chinese cotton textile workers have significant across-shift decrements in $\mathrm{FEV}_{1.0}$ in comparison with silk workers, after age, sex, stature, and smoking are controlled. This acute loss occurs in both symptomatic and asymptomatic cotton textile workers. Byssinotics tend to have greater across-shift decrements than nonbyssinotics with comparable work duration. These acute changes are noted in workers handling hand-picked cotton of medium to fine quality, and they suggest that handpicking alone is not sufficient to remove all of the fraction of the cotton plant containing the active agents responsible for pulmonary function changes and respiratory symptoms in cotton textile workers. These epidemiologic findings are consistent with laboratory investigations which have found a number of biologically active compounds in cotton dust that are unlikely to be avoided by handpicking alone (8).

Prospective epidemiologic studies of cotton textile workers in China may provide valuable insights into the long-term effects of cotton dust exposure. The stability of the workforce and the relative ease in contacting retirees and workers leaving exposed areas because of illness, all constitute a favorable environment in which to investigate the problem of cotton dustrelated lung disease and its potential solution.

\section{Acknowledgments}

This study was supported by grants from the Ministry of Health of the People's Republic of China, Harvard University, and the National Institute for Occupational Safety and Health (NIOSH grant no 1R030H0167701).

Technicians on the project were H-Y Fan, X-L Wang, and X-Y Yang. Ms L Pothier did the computer programming, and $\mathrm{Mr} M$ Wold the typing. The authors also gratefully acknowledge the assistance of Drs J Merchant, I Greaves, R Monson, and R Schilling. We are also grateful to the workers and staff of the Shanghai cotton and silk factories for their enthusiastic cooperation.

\section{References}

1. Beck GJ, Schachter EN. The evidence for chronic lung disease in cotton textile workers. Am Stat 37 (1983) 404-412.

2. Beck GJ, Schachter N, Maunder L, Schilling RSF. A prospective study of chronic lung disease in cotton textile workers. Ann Int Med 97 (1982) 645-651.

3. Berry G, McKerrow C, Molyneux M, Rossiter C, Tombleson $\mathbf{J}$. A study of the acute and chronic changes in ventilatory capacity of workers in Lancashire cotton mills. Br J Ind Med 30 (1973) 25-36.

4. Bouhouys A, Schoenberg JB, Beck GJ, Schilling RSF. Epidemiology of chronic lung disease in a cotton mill community. Lung 154 (1977) 167-186.

5. Braun DC, Jurgiel JA, Kuschak MC, Babyak MA. Prevalence of respiratory signs and symptoms among US cotton textile workers. J Occup Med 15 (1973) 414-419.

6. Buck M, Bouhouys A. A purified extract from cotton bracts induces airway constriction in humans. Chest 79 (1981) 43-49.

7. Christiani DC, Eisen EA, Wegman DH, Ye TT, Gong ZC, Lu PL, Dai HL. Respiratory disease in textile workers in the People's Republic of China: I Respiratory symptoms. Scand J Work Environ Health 12 (1986) $40-45$.

8. Edwards J. Mechanisms of disease induction. Chest 79 (1979) 39-43.

9. Eisen EA, Oliver LC, Christiani DC, Robins JM, Wegman DH. Effects of spirometry standards in two occupational cohorts. Am Rev Respir Dis 132 (1985) $120-124$.

10. Gardner, RM. ATS statement - Snowbird workshop on standardization of spirometry. Am Rev Respir Dis 119 (1979) 813-818.

11. International Cotton Advisory Committee. Cotton world statistics. Washington, DC 1977.

12. International Institute for Cotton. Cotton's importance to the developing world. Brussels 1976.

13. Jones RN, Diem SE, Glindmeyer V, Dharmarjan V, Hammad YY, Carr J, Weill H. Mill-effect and doseresponse relationships in byssinosis. $\mathrm{Br} \mathrm{J}$ Ind Med 36 (1979) 305-313.

14. McKerrow CB, McDermott M, Gilson JC, Schilling RSF. Respiratory function during the day in cotton workers: A study in byssinosis. Br J Ind Med 15 (1958) $75-83$.

15. Merchant J, Lumsden J, Kilburn K, O'Fallon WM, Uida JR, Germino VH, Hamilton JD. Dose-response studies in cotton textile workers. J Occup Med 15 (1973) $222-230$.

16. Schachter EN, Maunder LR, Beck GJ. The pattern of lung function abnormalities in cotton textile workers. Am Rev Respir Dis 124 (1984) 523-527.

17. Zuskin E, Valic F. Respiratory symptoms and ventilatory function changes in relation to length of exposure to cotton dust. Thorax 27 (1972) 454-458.

Received for publication: 25 February 1985 